\title{
Isotopic view on nitrate loss in Antarctic surface snow
}

\author{
Thomas Blunier, ${ }^{1}$ Grégoire L. Floch, ${ }^{1}$ Hans-Werner Jacobi, ${ }^{2}$ and Emmanuel Quansah ${ }^{2}$ \\ Received 17 March 2005; revised 24 May 2005; accepted 6 June 2005; published 8 July 2005.
}

[1] Massive post-depositional processes alter the nitrate concentration in polar firn where the annual snow accumulation is low. This hinders a direct atmospheric interpretation of the ice core nitrate record. Fractionation of nitrate isotopes during post-depositional nitrate loss may allow estimating the amount of nitrate loss in the past. We measured $\delta^{15} \mathrm{~N}$ of nitrate in two Antarctic surface cores from the Dome $\mathrm{C}$ area. In concert with the known concentration decrease with depth we observe an increase in the isotopic signature. Assuming a Rayleigh type process we find an isotope effect of $\varepsilon=-54 \%$. We measured the fractionation factor for photolysis in the laboratory and obtained $\varepsilon=-11.7 \pm 1.4 \%$. As the observed fractionation factor in the firn is much lower this rules out that photolysis in the surface snow is the main process leading to the dramatic nitrate loss in the top centimeters of the firn. Citation: Blunier, T., G. L. Floch, H.-W. Jacobi, and E. Quansah (2005), Isotopic view on nitrate loss in Antarctic surface snow, Geophys. Res. Lett., 32, L13501, doi:10.1029/2005GL023011.

\section{Introduction}

[2] Nitrate $\left(\mathrm{NO}_{3}^{-}\right)$deposition is the final fate of various $\mathrm{N}$ species in polar regions [Wolff, 1995]. Therefore, $\mathrm{NO}_{3}^{-}$from polar ice cores can potentially be used to investigate the atmospheric cycle of reactive nitrogen compounds. Nitrogen compounds have an important impact on atmospheric chemistry and the oxidation capacity of the atmosphere. Unfortunately, it turned out that $\mathrm{NO}_{3}^{-}$undergoes massive depositional and post-depositional processes in the firn. This hinders a direct atmospheric interpretation of the ice core $\mathrm{NO}_{3}^{-}$records [Röthlisberger et al., 2002].

[3] In Antarctica's low accumulation areas most of the $\mathrm{NO}_{3}^{-}$deposited at the surface is lost when the snow reaches a few decimeters depth [Mayewski and Legrand, 1990; Röthlisberger et al., 2000]. On the other hand, high accumulation sites (e.g., Summit, Greenland) presently preserve more than $90 \%$ of the initial $\mathrm{NO}_{3}^{-}$[Burkhart et al., 2004]. Here the annual cycle in the concentration is preserved and also the isotopic composition of $\mathrm{NO}_{3}^{-}$appears largely unaffected by post-depositional processes [Hastings et al., 2004].

[4] Mulvaney et al. [1998] describe the depositional processes affecting $\mathrm{NO}_{3}^{-}$in surface snow as a short-term equilibrium between the atmosphere and the snowpack where uptake and loss operate over the daily cycle with a

\footnotetext{
${ }^{1}$ Climate and Environmental Physics, Physics Institute, University of Bern, Bern, Switzerland.

${ }^{2}$ Alfred Wegener Institute for Polar and Marine Research, Bremerhaven, Germany.
}

Copyright 2005 by the American Geophysical Union. 0094-8276/05/2005GL023011 net loss over weeks and months. The seasonal $\mathrm{NO}_{3}^{-}$signal is preserved in this process although smoothed by diffusion. At very low accumulation sites the net loss of $\mathrm{NO}_{3}^{-}$ continues over several years and results in a complete loss of the annual signal for very low accumulations sites like Vostok, or Dome C.

[5] Key parameters determining $\mathrm{NO}_{3}^{-}$loss are established but are not clearly quantified [Dibb and Whitlow, 1996; Mayewski and Legrand, 1990; Röthlisberger et al., 2000]. They include temperature-accumulation, near surface air concentration, elevation, and presence of other species in snow (see Burkhart et al. [2004] for a compilation). Major candidates for the loss process in Antarctica as well as in Greenland are photolysis and re-evaporation. The latter may be related to wind driven effects [Mulvaney et al., 1998].

[6] In low accumulation sites snow remains relatively long in close proximity to the surface and thus in range of radiation of intense UV. Therefore, it seems possible that photolysis is the main process leading to the $\mathrm{NO}_{3}^{-}$loss [Röthlisberger et al., 2002]. Nonetheless, a model study suggests that only $40 \%$ of the $\mathrm{NO}_{3}^{-}$content can be depleted by photolysis for conditions found at Dome $\mathrm{C}$ [Wolff et al., 2002].

[7] The isotopic composition of $\mathrm{NO}_{3}^{-}$deposited on the snow depends on the $\mathrm{NO}_{3}^{-}$sources and the chemical reactions taking place during the transport to the deposition site [Freyer et al., 1996]. The isotope composition in freshly fallen snow is expected to equal the one in the atmosphere above the snow [Hastings et al., 2004]. Wagenbach et al. [1998] present Antarctic atmospheric $\delta^{15} \mathrm{~N}$ values varying from 0 to $-50 \%$. In a pioneer study Freyer et al. [1996] measured $\delta^{15} \mathrm{~N}$ of $\mathrm{NO}_{3}^{-}$in ice cores from Greenland, Antarctica and the Alps. They found increasing $\delta^{15} \mathrm{~N}$ values with the inverse accumulation rate for Holocene samples. This increase goes along with $\mathrm{a} \mathrm{NO}_{3}^{-}$concentration decrease for most sites, which is interpreted as originating from a loss process in the freshly fallen snow. Thus, the changes in the nitrogen (and oxygen) isotope composition of $\mathrm{NO}_{3}^{-}$may allow for the reconstruction of the atmospheric $\mathrm{NO}_{3}^{-}$concentration once the fractionation processes in the firn are understood.

[8] Here we investigate the first $15 \mathrm{~cm}$ of a firn core taken at the EPICA-DC site in the austral summer of 2003 by means of isotope analysis. Dome C $\left(75^{\circ} 06^{\prime} \mathrm{S}, 123^{\circ} 21^{\prime} \mathrm{E}\right.$, altitude $3233 \mathrm{~m}$ a.s.1.) has an annual mean temperature of $-54.5^{\circ} \mathrm{C}$ and a snow accumulation rate of $25.0 \mathrm{~kg} \mathrm{~m}^{-2}$ year $^{-1}$ (corresponding to about $7.4 \mathrm{~cm}$ of snow per year at the surface). At this low accumulation site the $\mathrm{NO}_{3}^{-}$ concentration decreases by orders of magnitude over the first $10 \mathrm{~cm}$ of firn. Release in the form of $\mathrm{HNO}_{3}$ and photolysis of $\mathrm{NO}_{3}^{-}$have been proposed as the cause for this loss [Röthlisberger et al., 2002]. Further we determined the fractionation factor for $\delta^{15} \mathrm{~N}$ of $\mathrm{NO}_{3}^{-}$associated with photolysis of $\mathrm{NO}_{3}^{-}$in snow. Based on laboratory and 


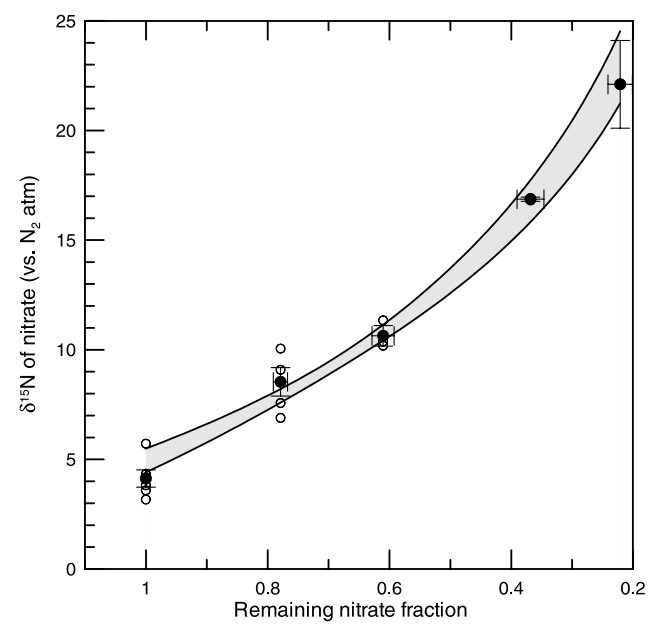

Figure 1. $\delta^{15} \mathrm{~N}$ of $\mathrm{NO}_{3}^{-}$measured in artificial snow versus the remaining $\mathrm{NO}_{3}^{-}$fraction after exposure to radiation. Circles are replicate isotope measurements using the same snow sample. Dots are mean values with error bars. The gray area represents the one sigma spread of the Monte Carlo simulations for the Rayleigh type process. The calculated fractionation factor is $\varepsilon=-11.7 \pm 1.4 \%$, where $\varepsilon=(\alpha-1)$.

firn measurements we are able to show that photolysis is not the sole process responsible for the $\mathrm{NO}_{3}^{-}$loss in the firn.

\section{Measurements}

[9] We measure $\mathrm{NO}_{3}^{-}$isotopes using a microbiological method developed by Sigman et al. [Sigman et al., 2001]. The method is based on the isotopic analysis of nitrous oxide $\left(\mathrm{N}_{2} \mathrm{O}\right)$ generated from $\mathrm{NO}_{3}^{-}$by denitrifying bacteria. We use Pseudomonas Chlororaphis, which lacks $\mathrm{N}_{2} \mathrm{O}$ reductase activity, and follow the protocol for bacteria cultivation by Sigman et al. [2001]. $2 \mathrm{ml}$ aliquots of bacteria slush are added to $20 \mathrm{ml}$ sample vials. Remnant $\mathrm{N}_{2} \mathrm{O}$ in the vials is removed by purging ultrapure helium carrier gas at $20 \mathrm{ml} / \mathrm{min}$ for $2-4$ hours, before melt water from the samples (or artificial snow) is added to the cultures. After an overnight incubation, the bacteria quantitatively converted $\mathrm{NO}_{3}^{-}$to $\mathrm{N}_{2} \mathrm{O}$. A poison $(\mathrm{NaOH})$ is injected to lysis the bacteria and stop the reaction. Using a helium carrier gas, $\mathrm{N}_{2} \mathrm{O}$ is stripped from each sample vial and analyzed by a GC/MS system (Thermo Finnigan MAT 253). With standards we obtain a reproducibility of $\pm 15 \mathrm{ppb}$ for the concentration and $\pm 0.2 \%$ for $\delta^{15} \mathrm{~N}$. All measurements are made versus a $\mathrm{N}_{2} \mathrm{O}$ standard gas. Each batch of samples includes samples with $\mathrm{NO}_{3}^{-}$standards (IAEA-N3), which have an assigned $\delta^{15} \mathrm{~N}$ of $4.7 \%$ versus atmospheric $\mathrm{N}_{2}$.

[10] Our system is designed to work with a sample amount of 10 nmole of $\mathrm{NO}_{3}^{-}$. To obtain 10 nmole of $\mathrm{NO}_{3}^{-}$ the volume of the sample (i.e., the amount of snow) added to the bacteria slush varies depending upon the concentration of each sample. As the concentration in the snow decreases rapidly over the first few centimeters, the sample volumes vary between 1 and $8 \mathrm{ml}$ from the surface to $15 \mathrm{~cm}$ depth. We observe that for low concentration samples the transfer of $\mathrm{NO}_{3}^{-}$to $\mathrm{N}_{2} \mathrm{O}$ is slightly reduced. Along with the reduced transfer comes a strong $\delta^{15} \mathrm{~N}$ fractionation of several per mil. We overcame this problem by adding more bacteria to the low $\mathrm{NO}_{3}^{-}$concentration samples. The bacteria concentration was kept constant at values corresponding to the sample protocol of Sigman et al. [2001] regardless of the sample size.

\section{Laboratory Experiment}

[11] Fractionation factors for the various possible reactions in firn are unknown. We determined the fractionation factor for photolysis of $\mathrm{NO}_{3}^{-}$in a laboratory experiment. At AWI artificial snow was produced from a solution of $\mathrm{NaNO}_{3}$ in ultrapure water (MilliQ) with an initial concentration of about $780 \mathrm{ppb}$. The solution was sprayed into a Styrofoam cup filled with liquid nitrogen. The generated ice chunks were ground and passed through a sieve. After storage over night, the artificial snow samples were exposed to intense UV and visible radiation in the range of $200 \mathrm{~nm}$ to $\sim 900 \mathrm{~nm}$ [see Jacobi et al., 2005]. The experiments were performed at $-20^{\circ} \mathrm{C}$ with exposition times ranging from 0.5 to $3 \mathrm{~h}$.

[12] Previous experiments performed under identical conditions regarding initial $\mathrm{NO}_{3}^{-}$concentration, radiation intensity, and temperature demonstrated an exponential decay of $\mathrm{NO}_{3}^{-}$within the first $5 \mathrm{~h}$ of the experiments with a photolysis rate of $0.5 \mathrm{~h}^{-1}$ [Quansah, 2004]. This photolysis rate was used to calculate remaining $\mathrm{NO}_{3}^{-}$fractions in the snow samples used for the isotope analyses. In the previous experiments, nitrite concentrations showed a steep increase followed by a fast decrease leading to a maximum in the nitrite concentrations after experiments lasting between 0.5 and $1 \mathrm{~h}$. Using the previously observed nitrite concentrations, we estimate that the nitrite-to-nitrate ratios are equal to or smaller than 0.08 in all samples used for the isotope analysis. Since the experiments were performed in closed cells, it is not clear if the detected nitrite is a decay product or if it is formed from decay products, which were not removed during the experiments. We also do not completely rule out that some $\mathrm{NO}_{3}^{-}$is reformed from gaseous decay products like $\mathrm{NO}_{2}$. The exposed snow was transported to Bern for isotope analysis (Figure 1).

[13] We calculate the fractionation factor of the photolysis reaction for this Rayleigh type experiment.

$$
\frac{\mathrm{R}_{f}}{\mathrm{R}_{0}}=f^{(\alpha-1)}
$$

$\mathrm{R}_{0}$ and $\mathrm{R}_{f}$ are the isotope ratios ${ }^{15} \mathrm{~N} /{ }^{14} \mathrm{~N}$ of the initial $\mathrm{NO}_{3}^{-}$ and the remaining $\mathrm{NO}_{3}^{-}$fraction $f$. The same equation can be written with concentrations and $\delta$-values versus an arbitrary standard with the isotope ratio value $\mathrm{R}_{\mathrm{St}}$.

$$
\begin{gathered}
\frac{\mathrm{R}_{f}}{\mathrm{R}_{\mathrm{St}}} \cdot \frac{\mathrm{R}_{\mathrm{St}}}{\mathrm{R}_{0}}=\frac{\delta_{f}+1}{\delta_{0}+1}=f^{(\alpha-1)} \\
\ln \left(\delta_{f}+1\right)=(\alpha-1) \cdot \ln f+\ln \left(\delta_{0}+1\right)
\end{gathered}
$$

[14] A simple linear regression of the data allows the calculation of the fractionation factor (Equation 3). However, this method does not account for the individual 


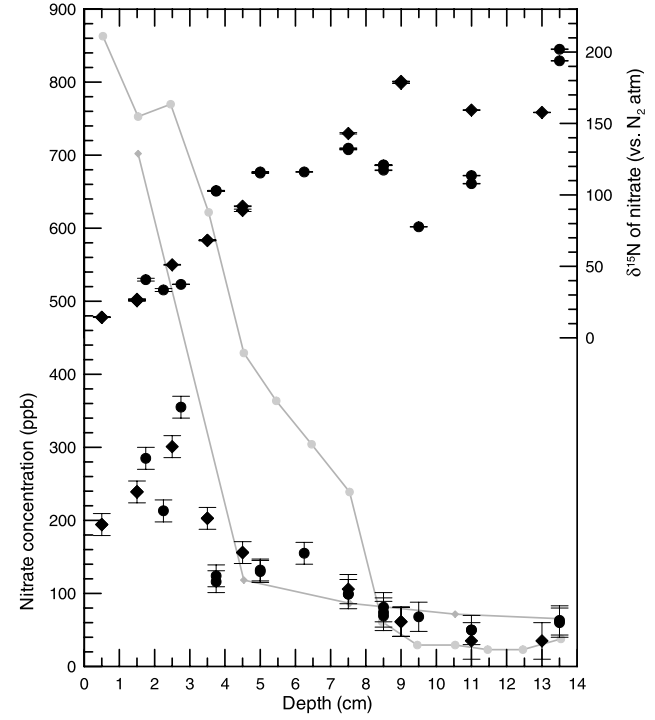

Figure 2. $\delta^{15} \mathrm{~N}$ and concentrations of $\mathrm{NO}_{3}^{-}$from the Dome $\mathrm{C}$ area versus depth. Grey dots and diamonds are concentration measurements from a snow pit taken in 1999 [Röthlisberger et al., 2000]. Dots and diamonds are individual samples from adjacent cores taken in 2003. Error bars show one sigma analytical errors. Concentrations were estimated from the mass spectrometer measurements.

uncertainties for $\delta^{15} \mathrm{~N}$ values and concentrations, which are quite substantial. Therefore, we do a Monte Carlo simulation taking into account these uncertainties (Figure 1). The exposition times are used to calculate the $\mathrm{NO}_{3}^{-}$concentrations, which are accurate to the $2 \%$ range. We obtain a fractionation factor of $\varepsilon=-11.7 \pm 1.4 \%$, where $\varepsilon=(\alpha-1)$. Our bacteria do feed on $\mathrm{NO}_{3}^{-}$and nitrite forming finally $\mathrm{N}_{2} \mathrm{O}$. Therefore the calculated fractionation factor includes a fraction of maximal $8 \%$ nitrite in our samples (see above). Depending on how this nitrite is formed we may under- or overestimate the photolytic fractionation factor for $\mathrm{NO}_{3}^{-}$.

\section{Antarctic Samples}

[15] Two adjacent firn cores were sampled at Dome C during the austral summer of 2003. The cores were stored in polyethylene tubes and kept below $-20^{\circ} \mathrm{C}$ until analyzed. We measured the first $15 \mathrm{~cm}$ of both cores, which covers about two years of precipitation. Both concentration profiles are typical for Dome $\mathrm{C}$ and low accumulations sites, with a drastic drop of $350 \mathrm{ppb}$ to $50 \mathrm{ppb}$ in the first ten centimeters of the firn (Figure 2). In deeper strata the concentration remains stable at low levels [Röthlisberger et al., 2000].

[16] Samples were taken from the inner and the outer part of the core. We observe systematically higher $\mathrm{NO}_{3}^{-}$concentrations and lower isotopic values in the outer section of the cores. On average the concentration difference between outer and inner sample is $41 \pm 11 \mathrm{ppb}$ with an average $\delta^{15} \mathrm{~N}$ difference of $-26 \pm 6 \%$. Apparently the polyethylene tube is a source of light $\mathrm{NO}_{3}^{-}$. In a core sampled and stored in a similar way than the Dome $\mathrm{C}$ samples discussed here, we investigated how deep the contamination entered the core. We found that the contamination has entered the outermost $2 \mathrm{~cm}$ of the core. As these measurements have been made six months later than the isotope measurements, we are confident that our Dome $\mathrm{C}$ results from the inner core section are free from a contamination from the sampling tubes.

[17] In Figure $3, \delta^{15} \mathrm{~N}$ values of the inner section are plotted against $\mathrm{NO}_{3}^{-}$concentrations. The resolution depends on the $\mathrm{NO}_{3}^{-}$concentration of the ice core. In the top $2 \mathrm{~cm}$ we measured samples every $0.5 \mathrm{~cm}$. Further down the core the resolution decreases due to the lower concentration in order to match the sample size minimum of about 10 nmoles of $\mathrm{NO}_{3}^{-}$.

\section{Results and Discussion}

[18] At high accumulation sites annual variations in concentration and isotope values are visible in the first meter of firn [Hastings et al., 2004]. No annual variations are obvious in the concentration [Röthlisberger et al., 2000] or nitrogen isotope records (Figure 2) at Dome C. The two cores and similar concentration studies show, that both concentration and isotope signals are highly variable in adjacent cores. Nevertheless, a clear trend of lower concentrations with increasing isotope values is visible. Apparently the removal process for $\mathrm{NO}_{3}^{-}$prefers the lighter isotope. Assuming that $\mathrm{NO}_{3}^{-}$is removed irreversibly from the firn we can use the Rayleigh equation to calculate the fractionation coefficient $\alpha$ of the sum of the processes involved. For the natural samples we do not know the original surface concentration and, therefore, the fraction $f$. However, the fractionation coefficient can also be calculated without that knowledge. We substitute $f=\mathrm{C}_{f} / \mathrm{C}_{0}$ where $\mathrm{C}_{0}$ and $\mathrm{C}_{f}$ are the original surface concentration and the concentration of the remaining fraction $f$, respectively and obtain:

$$
\ln \left(\delta_{f}+1\right)=(\alpha-1) \ln \mathrm{C}_{f}+\underbrace{\left[\ln \left(\delta_{0}+1\right)-(\alpha-1) \ln \mathrm{C}_{0}\right]}_{\mathrm{b}}
$$

[19] We find $\varepsilon=-53.9 \%$, where $\varepsilon=(\alpha-1)$ (Figure 3). Due to the high local variability the uncertainty of this isotope effect is relatively large $(9.7 \%)$. As the fractionation

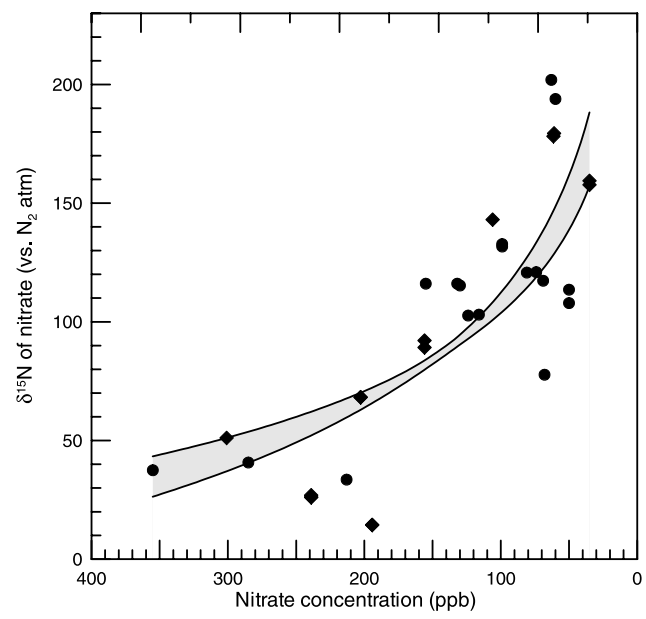

Figure 3. $\delta^{15} \mathrm{~N}$ of $\mathrm{NO}_{3}^{-}$versus concentration for samples taken in the austral summer of 2003 (Figure 2). The gray area represents the one sigma spread of the Monte Carlo simulations for a Rayleigh type process. 
coefficient for photolysis is only $\varepsilon=-11.7 \pm 1.4 \%$ we conclude, that photolysis is probably not the dominant loss process in the near surface snow.

[20] There is, however, the possibility that photolysed $\mathrm{NO}_{3}^{-}$is recycled, accumulating photolytic fractionations to the observed isotope effect. Such a process would involve the photolysis of $\mathrm{NO}_{3}^{-}$in the snow generating nitrogen oxides $\left(\mathrm{NO}_{\mathrm{x}}\right)$, its release to the firn air [Jones et al., 2000], the reoxidation of $\mathrm{NO}_{\mathrm{x}}$ to $\mathrm{NO}_{3}^{-}$in the gas phase, which then is again deposited to the snow. Such a recycling in the atmosphere could explain the strong fractionation observed in the natural snow only, if it involves at least one step with a strong $\delta^{15} \mathrm{~N}$ enrichment. Such an enrichment has been observed, however, not under conditions that lead to a significant $\mathrm{NO}_{3}^{-}$production. Under conditions that lead to a significant production of $\mathrm{NO}_{3}^{-}$the redeposited $\mathrm{NO}_{3}^{-}$is isotopically light [Heaton et al., 2004]. This is in line with a recent finding from Hastings et al. [2004] and makes it unlikely that recycling of photolysed $\mathrm{NO}_{3}^{-}$explains the observed isotope fractionation in the firn.

[21] At Neumayer Station $\left(70^{\circ} 39^{\prime} \mathrm{S}, 08^{\circ} 15^{\prime} \mathrm{W}\right)$ the isotope values of $\mathrm{NO}_{3}^{-}$vary between about $0 \%$ in the austral summer and $-50 \%$ in the austral winter. The annual mean value for the time period 1986 to 1992 is $-21.6 \pm 9.9 \%$ [Wagenbach et al., 1998]. First measurements on filter samples from the Dome $\mathrm{C}$ site show a similar signal. The top samples ("surface") show relatively low concentrations compared to the values found by Röthlisberger et al. [2000] with elevated isotope values of up to $+40 \%$. It is likely that we did not catch the surface snow or that the first sample suffered from loss processes during the transport. The Rayleigh approach allows also the calculation of a surface concentration based on a surface isotope value from the intercept $b$ of the regression (Equation 4).

$$
\mathrm{C}_{0}=\left(\frac{\delta_{0}+1}{\mathrm{e}^{\mathrm{b}}}\right)^{1 /(\alpha-1)}
$$

[22] Assuming that the initial $\delta^{15} \mathrm{~N}$ signature of $\mathrm{NO}_{3}^{-}$in fresh snow corresponds to the annual mean value found for Neumayer Station, we calculate a surface $\mathrm{NO}_{3}^{-}$concentration of about $900 \mathrm{ppb}$ consistent with published data for the Dome C area [Röthlisberger et al., 2000].

[23] We are aware that assuming a Rayleigh type fractionation is an oversimplification of the processes in the firn. Nevertheless, this simple approach demonstrates that photolysis alone is not responsible for the loss process in the near surface snow. Wolff et al. [2002] estimate that only $40 \%$ of the $\mathrm{NO}_{3}^{-}$is removed by photolysis reactions. With our data this would result in a fractionation factor of the other non photolytic process(es) of about $-80 \%$. The most promising candidate is re-evaporation of $\mathrm{NO}_{3}^{-}$. The next step will be to simulate re-evaporation in the lab and to determine its fractionation factor.

[24] Once fractionation factors for individual loss processes in the firn are known they will help to disentangle their relative contribution to the total $\mathrm{NO}_{3}^{-}$loss. If we understand the fractionation of $\mathrm{NO}_{3}^{-}$isotopes during postdepositional processes isotope measurements from ice cores may ultimately allow estimating the amount of post-depositional $\mathrm{NO}_{3}^{-}$loss in the past. Combined with the existing high resolution $\mathrm{NO}_{3}^{-}$concentration records it may be possible to reconstruct the true past atmospheric $\mathrm{NO}_{3}^{-}$concentration in polar areas.

[25] Acknowledgments. This work was supported by the University of Bern, the Swiss National Science Foundation, and the German Research Foundation (DFG). We thank Danny Sigman (Princeton University) for his open door policy concerning the denitrifier method and Ernst Schweingruber (University of Bern) for his support with the bacteria cultures. We also thank Manuel Hutterli, Regine Röthlisberger (University of Bern), Dietmar Wagenbach (University of Heidelberg), and Eric Wolff (British Antarctic Survey) for discussion and comments. We thank the EPICA crews for their work in the field. We also thank Meredith G. Hastings and an anonymous reviewer for critical but constructive comments.

\section{References}

Burkhart, J. F., M. Hutterli, R. C. Bales, and J. R. McConnell (2004), Seasonal accumulation timing and preservation of nitrate in firn at Summit, Greenland, J. Geophys. Res., 109, D19302, doi:10.1029/ 2004JD004658.

Dibb, J. E., and S. I. Whitlow (1996), Recent climate anomalies and their impact on snow chemistry at South Pole, 1987-1994, Geophys. Res. Lett., 23, 1115-1118

Freyer, H. D., K. Kobel, R. J. Delmas, D. Kley, and M. R. Legrand (1996), First results of $\mathrm{N}-15 / \mathrm{N}-14$ ratios in nitrate from alpine and polar ice cores, Tellus, Ser. B, 48, 93-105.

Hastings, M. G., E. J. Steig, and D. M. Sigman (2004), Seasonal variations in $\mathrm{N}$ and $\mathrm{O}$ isotopes of nitrate in snow at Summit, Greenland: Implications for the study of nitrate in snow and ice cores, J. Geophys. Res., 109, D20306, doi:10.1029/2004JD004991.

Heaton, T. H. E., P. Wynn, and A. M. Tye (2004), Low ${ }^{15} \mathrm{~N} /{ }^{14} \mathrm{~N}$ ratios for nitrate in snow in the high Arctic $\left(79^{\circ} \mathrm{N}\right)$, Atmos. Environ., 38, $5611-5621$.

Jacobi, H.-W., B. Kwakye-Awuah, and O. Schrems (2005), Photochemical decomposition of hydrogen peroxide $\left(\mathrm{H}_{2} \mathrm{O}_{2}\right)$ and formaldehyde (HCHO) in artificial snow, Ann. Glaciol., in press.

Jones, A. E., R. Weller, E. W. Wolff, and H. W. Jacobi (2000), Speciation and rate of photochemical $\mathrm{NO}$ and $\mathrm{NO}_{2}$ production in Antarctic snow, Geophys. Res. Lett., 27, 345-348.

Mayewski, P. A., and M. R. Legrand (1990), Recent increase in nitrate concentration of Antarctic snow, Nature, 346, 258-260.

Mulvaney, R., D. Wagenbach, and E. W. Wolff (1998), Postdepositional change in snowpack nitrate from observation of year-round near-surface snow in coastal Antarctica, J. Geophys. Res., 103, 11,021-11,031.

Quansah, E. (2004), Photochemical decomposition of nitrate $\left(\mathrm{NO}_{3}^{-}\right)$in artificial snow, M.S. thesis, Univ. of Bremen, Bremen, Germany.

Röthlisberger, R., M. A. Hutterli, S. Sommer, E. W. Wolff, and R. Mulvaney (2000), Factors controlling nitrate in ice cores: Evidence from the Dome C deep ice core, J. Geophys. Res., 105, 20,565-20,572.

Röthlisberger, R., et al. (2002), Nitrate in Greenland and Antarctic ice cores: A detailed description of post-depositional processes, Ann. Glaciol., 35, 209-216.

Sigman, D., K. L. Casciotti, M. Andreani, C. Barford, M. Galanter, and J. K. Böhlke (2001), A bacterial method for the nitrogen isotopic analysis of nitrate in seawater and freshwater, Anal. Chem., 73, $4145-4153$.

Wagenbach, D., M. Legrand, H. Fischer, F. Pichlmayer, and E. W. Wolff (1998), Atmospheric near-surface nitrate at coastal Antarctic sites, J. Geophys. Res., 103, 11,007-11,020.

Wolff, E. W. (1995), Nitrate in Polar Ice, in Ice Core Studies of Global Biogeochem. Cycles, edited by R. J. Delmas, pp. 195-224, Springer, New York.

Wolff, E. W., A. E. Jones, T. J. Martin, and T. C. Grenfell (2002), Modelling photochemical $\mathrm{NO}_{x}$ production and nitrate loss in the upper snowpack of Antarctica, Geophys. Res. Lett., 29(20), 1944, doi:10.1029/ 2002GL015823.

T. Blunier and G. L. Floch, Climate and Environmental Physics, Physics Institute, University of Bern, Sidlerstrasse 5, CH-3012 Bern, Switzerland. (blunier@climate.unibe.ch)

H.-W. Jacobi and E. Quansah, Alfred Wegener Institute for Polar and Marine Research, Am Handelshafen 12, D-27570 Bremerhaven, Germany. 